\title{
Optimising CSR Funds as a Source of Funding for Regional Development in Indonesia
}

\author{
Iskandar $^{1}$ \\ Tasmanian School of Business and Economics, University of Tasmania - Australia \\ Ministry of Finance - Indonesia
}

\begin{abstract}
The limited source of development funding forced local government to find an innovative alternative. One of them is Corporate Social Responsibility (CSR). Although the prospect of CSR Funds as a source of local revenue is relatively big, mismanaging it could lead to a fraud which causes an underachieving the purpose of CSR itself. This paper specifically discussed an alternative budgeting process for local government's activities that CSR was its source of fund. The purpose of this paper is to provide applicable suggestions for local government in optimising CSR Funds as a source of local development funding that minimising the potential fraud. To achieve this objective, this paper used a qualitative approach through analysis of relevant regulations and previous studies. This paper argued that receiving CSR Funds in the form of goods or services could help local government to reduce the risk of fraud, both from a local financial management perspective and from the CSR point of view. In addition to assisting local government with an alternative optimisation source of development funding, this paper also contributed to providing input for the preparation of the National Medium-Term Development Plan (RPJMN) 2020-2024 that is intertwined with the Sustainable Development Goals (SDGs). The proposed strategies were divided into short-term, medium-term, and long-term policies such that it can be implemented with clear and measurable targets.
\end{abstract}

Keywords: CSR; APBD; local government; budgeting system; SDGs.

\footnotetext{
${ }^{1}$ Iskandar is a PhD candidate at University of Tasmania, Hobart, Australia and a staff at Directorate General of Trea-
} sury, Ministry of Finance, Jakarta, Indonesia. Email address: iskandar.060105658@gmail.com 


\title{
Optimising CSR Funds as a Source of Funding for Regional Development in Indonesia
}

\author{
Iskandar - University of Tasmania, Ministry of Finance
}

\section{Background}

One of the objectives of the Indonesian government, as stated in The 1945 Constitution of the Republic of Indonesia, is to improve the public welfare of the people of Indonesia. In order to ensure its success, a new institutional arrangement was introduced in 1999. Law 23/2014 and Law 33/2004, which replaced an earlier law from 1999, provide a framework and legal standing for local government in Indonesia to gain more authority from central government. Under the new arrangement, Law $23 / 2014$, local government is responsible to carry out all administrative affairs except for foreign affairs, defence, security, judicial affairs, monetary and fiscal policy, and religion, which handled by central government. The Indonesian government is shifting their governmental system from centralised development planning regime to decentralisation system with greater responsibility and authority for managing their resources. Such design facilitates the local government in responding the people need effectively and delivering public services efficiently (Rusmin, Astami, and Scully 2014).

With the principle of "money follows function", the central government mandated by Law 33/2004 to allocate Transfer Fund for each responsibility delegated to local government. The amount of money was varied depending on the characteristic of local government and the type of authority given. Central Government Financial Statements (Laporan Keuangan Pemerintah Pusat/LKPP) shown that, on average, more than $36 \%$ of total central government expenditures went to local governments annually from 2014 to 2016.

Notwithstanding its advantages, the autonomy given to the local government did not concur with the ability to plan and stimulate economic development in their region. This condition happened due to the previous role of local government as “executing agencies" of central government's policy and projects (Nasution 2016). The opinion is supported by the fact that after more than 15 years of autonomy, most of the local governments still made the Transfer Fund as the backbone of their budget (APBD). The data from Directorate General of Fiscal Balance, Ministry of Finance of Indonesia shown that in 2014-2016, around 70\% of local government in Indonesia source at least two-thirds of their expenditure from the Transfer Fund from the central government.

High dependency on central government's funding hindered the local 
government to foster an initiative for economic development within their jurisdiction. Most of the transferred funds from central government are earmarked grants. Therefore, local government could not rely on Transfer Funds as the source of funding for their development initiatives. Consequently, local government needs to find other resources to fund their development plans. One of them is Corporate Social Responsibility (CSR) funds. However, CSR Funds contribution to local government is not on budgeting system. Corruption Eradication Commission (KPK) alarmed head of local government regarding this practice. According to Saut Situmorang, vice chairman of KPK, putting CSR Funds off budget limits control and supervision from the local house of representative (Dewan Perwakilan Rakyat Daerah/DPRD) and local government auditor (Isnanto 2017). Limited supervision on the flow of CSR Funds to local government increases the risk of fraud.

This paper aims to provide an alternative resource of development funding for local government. Its focus is on the strategy to improve the accountability of the flow of CSR Funds to local government by incorporating it into local government budgeting system. To achieve its objective, the present study used qualitative approach by analysing relevant regulations and previous studies. This paper suggested local government to receive CSR Funds in goods and services in order to reduce the potential fraud both in local government financial management, e.g. corruption, and in CSR governance, e.g. misuse of CSR Funds. There are three strategies proposed by this study: short-term, medium-term, and long-term strategy. Each strategy is independent and can be implemented simultaneously. By following the proposed strategies, local government could have a clear and measurable policy to integrate CSR Funds into their budgeting system as an alternative funding for local government's development initiatives.

This study contributes to enhancing the capacity of local government to promote development initiative in their region. By focusing on optimising the use of CSR as a source of development funding, this paper also contributes on providing suggestions for National Medium-Term Development Plan (RPJMN) 2020-2024 that integrated to Sustainable Development Goals (SDG).

The rest of the paper is organised as follows. Literature reviews on local government budgeting system and CSR are presented in Section 2. Section 3 describes the method that used in this paper, followed by Findings and Discussion Section. Lastly, conclusions were drawn in section 5. 


\section{Literature Review}

The decentralisation of government system in Indonesia was legislated in Law 23/2014 concerning Local Administration, which replaced Law 22/1999. According to the 1945 Constitution of the Republic of Indonesia, local government govern and manage their own administrative affairs with the principles of autonomy and assistance task. These arrangements are directed towards speeding up the creation of public welfare through the improvement of services, public participant, regional competitiveness based on the principles of democracy, equitable distribution, justice, and peculiarity of regions within the frame of the Unitary Republic of Indonesia. The constitution guarantees the wide range of autonomy for local government except in matters specified by law to be the affairs of the central government, which is detailed in Law 23/2014 as foreign affairs, defence, security, judicial affairs, monetary and fiscal policy, and religion.

The delegation of most administration affair to local government requires the transfer of funding. Law 33/2014 concerning Financial Balance between Central Government and Local Government, which replaced Law 25/1999, give a legal foundation for the provision of finance to support the implementation of autonomy based on the principle of "money follows function". Furthermore, law $33 / 2014$ regulates the source of funding for local government to exercise local government administration affair, that is Own Source Revenues (Pendapatan Asli Daerah/PAD), Transfer Fund (Dana Perimbangan), others legitimate revenue (Lain-lain pendapatan yang sah), and Local government loan (Pinjaman Daerah).

$\mathrm{PAD}$ is the revenues that are received by the local government from their jurisdiction. This revenue is on local government reference how to use it as a manifestation of decentralisation. Transfer Fund is the funding from central government to finance their administration affair as consequences of autonomy. Its purpose is to reduce the fiscal gap between central government and local government and within local governments. In general, there are three categories of Transfer Fund: Shared Fund (Dana Bagi Hasil/DBH), General Allocation Fund (Dana Alokasi Umum/DAU), and Special Allocation Fund (Dana Alokasi Khusus/ DAK). Law 33/2014 made mandatory for the central government to allocate at least $26 \%$ of their net domestic revenue for DAU. Others legitimate revenue involve of Grant Revenues and emergency fund. Local government might receive Grant from the third party in form of currency, goods, or services. All grants need to be registered in a document of agreement between local government and grantor. In the case where the grantor is from other nation, the central government is acting as 
the grantee. Central government allocates emergency fund for local government in one of two conditions: (1) experiencing a major disaster or extraordinary incident or both, and (2) facing solvability crisis. The local government loan is a source of funding for economic growth acceleration and public services enhancement.

The 1945 Constitution of the Republic of Indonesia sets the objectives of forming a government of the state of Indonesia. To achieve these objectives, Indonesian government need to provide an effective, efficient, sustainable development through national development planning. Moreover, the enactment of Law 23/2014 gave the local government authority to manage their region with less intervention from central government, including on local development planning. Accordingly, coordination between central government and local governments are necessary to harmonise and align their development planning as oneintegrated nationaldevelopment planning. For this reason, National Development Planning System was introduced in Law 25/2004.

The law provides a legal framework for central and local governments in Indonesia to administer the development planning. Under Law 25/2004, the National Development Planning System be regarded as a one unify national development planning that is broken down into long-term, medium-term, and short-term that runs by the central government and local governments as the administrator of its respective level. National Long-Term Development Plan (RPJPN) is a translation of the objective of forming a government of the state of Indonesia as stated in The 1945 Constitution of the Republic of Indonesia. RPJPN contains vision, mission, and direction of national development in 20 years period. Central government uses RPJPN to construct National Medium-Term Development Plan (RPJMN) which contains translation of vision, mission, and presidential programs. RPJMN covers national development strategy, general policy, Ministries/Agencies and inter Ministries/ Agencies programs, territorial and interterritorial programs, macroeconomic framework, and indicative funding for the next five years. The RPJMN is implemented every year as Government Annual Work Plan (Rencana Kerja Pemerintah/RKP) that encompass detailed development priorities, macroeconomic framework plans including fiscal policy directions, and indicative funding framework.

From the local government's perspectives, the National Development Planning System is reflected in Regional Development Plan, which adapt the National Development Plan. Regional Long-Term Development Plan (RPJPD) contains vision, mission, and direction of regional development that refers to RPJPN. Regional Medium-Term Development Plan (RPJMD) consists of the interpretation of vision, mission, and programs of the head of local government, which in lines with RPJPD 
and refers to RPJPN. RPJMD covers regional financial policy, regional development strategy, general policy, SKPD and inter SKPD programs, territorial programs, along with its work plans and indicative funding framework. Local Government Annual Work Plan (Rencana Kerja Pemerintah Daerah/RKPD) is the annually detailed interpretation of RPJMD that encompass regional economic framework plan, local government development priorities and work plans along with its funding.

Furthermore, Law 25/2004 detailed the preparations of the plans that includes (1) preparing draft of development plans that is technocratic, comprehensive, and measurable; (2) preparing draft of action plans referring to the draft of development plans; (3) involving citizen participation and synchronising the development plans in a forum called Deliberation of Development Plans (Musyawarah Perencanaan Pembangunan/Musrenbang); and (4) finalising the draft of development plans. Once it is final, the establishment of the development plans is varied. RPJPN and RPJPD are enacted in Law and Perda respectively. RPJMN and RKP are legislated in Presidential Decree, while RPJMD and RKPD are in Head of Local Government Decree.

The State Finances Law 17/2003 mandated local government and DPRD to establish APBD in order to guaranty the delivering of public services is achievable. APBD is a local government's financial planning document that reflects RKPD for the respective budget year (budget year in Indonesia starts 1st of January to 31st December). Regulation of Ministry of Home Affairs 13/2006 concerning the Guidelines of Local Government Financial Management has detailed the processes of APBD planning as shown in Figure 1.

Figure 1. APBD Planning Process

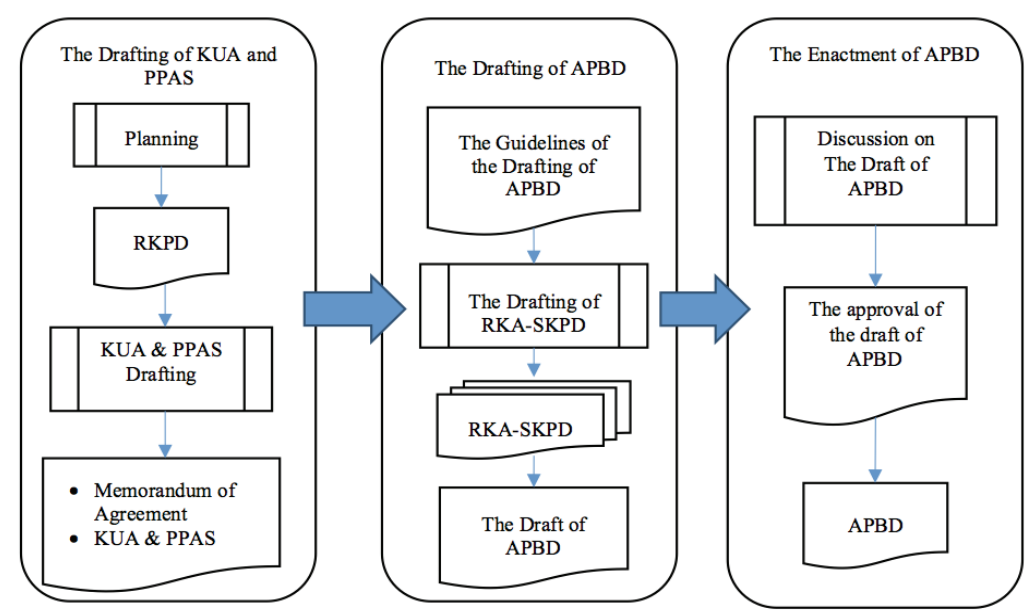

Source: Regulation of Ministry of Home Affairs 13/2006 
The processes begin with composing General Policy of APBD (Kebijakan Umum APBD/KUA) and Priorities and Plafond of Provisional Budget (Prioritas dan Plafon Anggaran Sementara/PPAS). KUA is a document of local government's policy on revenues, expenditures, and financing of APBD along with its underlying assumption based on RKPD. It covers the target performance of local government's programs, revenues projection, allocation of expenditure, and source of funding. A consultation meeting with DPRD is compulsory to discuss KUA. It is required for DPRD to approve the draft of KUA before its finalised.

PPAS is a draft of local government's programs priority and budget plafond. It is a guidance for each local government spending unit (Satuan Kerja Perangkat Daerah/SKPD) to assemble their Budget Allocation Plan of SKPD (Rencana Kerja Anggaran - SKPD/RKA-SKPD). The local government uses the final approved version of KUA to establish PPAS. The compilation of PPAS is done by defining the obligatory and optional businesses based on its scale of priority, ordering the list of programs on each business, determining the provisional budget plafond for each program. Once it is compiled, local government hold another discussion with DPRD regarding PPAS. The final version of PPAS is called Priorities and Plafond of Budget (Prioritas dan Plafon Anggaran/PPA). The product of these processes is Memorandum of Agreement (Nota Kesepakatan) between the head of local government and chief of DPRD for KUA and PPA.

Referring to the memorandum of agreement, the local government launches the Guidelines of RKA-SKPD drafting for SKPD. The guidelines include PPA for each program and SKPD, synchronisation between programs of SKPD and its performance, the time frame for RKA-SKPD drafting, the critical point to concern by SKPD, and other supplementary documents such as the format of RKA-SKPD, KUA, and PPA. All RKA-SKPD are reviewed and updated, if required, according to KUA, PPA, performance indicators of SKPD, and others. When the RKA-SKPDs are fixed, the local government starts drafting the regional regulation (peraturan daerah/Perda) concerning APBD and passing it to DPRD.

Once it is received, DPRD arranges discussion the draft of Perda APBD with local government. The focuses are on its conformity to KUA and PPA that has been approved by DPRD. The discussion comes to conclusion with the head of local government and chief of DPRD take collective decision making on the approval of the draft of Perda APBD.

While not having it under one specific law, Indonesian government have put strong concern on CSR in many legislations. Law 22/2001 concerning Oil and Natural 
Gas implicitly mandated CSR as part of every oil and natural gas activities' contract. Law 25/2007 concerning Capital Investment requested every investor to implement CSR within their company. More detail, law 40/2007 concerning Indonesian limited liability company (Perseroan Terbatas/PT) is encouraging CSR for every company. Nonetheless, the law only makes it compulsory for the natural resources companies. The CSR plans need to be stated in business plans approved by Board of Commissioners or General Meeting of Shareholders. It also obligatory for the company to disclose its CSR activities in the financial statements. By this law, the government have authority to give sanction as punishment to the disobedience company.

Many recent research has been done with focuses on the use of CSR as the source of development funding. Gumuru (2014) suggested that the role of local government in identifying the work plans for CSR Funding could increase the performance of CSR to support development regional level. Machmud (2015) argued that it was plausible to use CSR as an alternative funding to the limited budget for infrastructure projects. Muallidin et al. (2016) took Special Region of Yogyakarta and Central Java Province as a case study of local government's policy of CSR. They stressed the role of a strong policy to have a successful CSR implementation. Moreover, Gumuru (2014), Machmud (2015), and Muallidin et al. (2016) agreed on the establishment of communication between companies and local government to synchronise CSR programs with local government development plans.

Ward, Wilson, and Zarsky (2007) gave rational behind the involvement of government in CSR, which is defensive and proactive justification. The defensive justification aims to make sure the CSR implementations within their jurisdiction are in line with national economic and government development plans. On the other hand, the proactive justification gives the government an opportunity to enhance the public benefits of CSR implementation. While in the defensive justification, the government's role is more as coordinator, with the proactive justification is an initiator.

\section{Methods/Methodology}

This research used statements and articles of legislation related to the topic as the data. The main source of data used in this study was Law 17/2003 concerning the state finance, law 40/2007 concerning Indonesian limited liability company (Perseroan Terbatas/PT), Law 23/2014 concerning Local Administration, Law 33/2014 concerning Financial Balance between Central Government and Local Government, Law 25/2004 concerning National Development Planning System, along with its relevant derivative legislation. 
The present study used a qualitative approach through analysis of relevant regulations and previous studies. Following Subekan (2016), the data analysis was done by investigating the relevant statements and articles in the legislation in order to address the objective of the present research. It included disclosing the relevant statements and articles, understanding its meaning, comparing it to others related articles, and examining its context. Disclosure of statements and articles of legislation was made by citing the statements and articles of the relevant legislation to avoid misquoting. Understand the correct meaning of the article was done by looking at the explanation of the law. A comprehensive analysis was guaranteed by comparing the article to another article both within the same legislation and in others. Moreover, the new possible arrangements were proposed by examining the article to preserve its substances and focuses.

\section{Results, Analysis, and Discussions}

Article 6 of Law 17/2013 confirmed the role of the President as head of government to hold power on the state finances management. This power then delegated to head of local government to manage local government finances. Furthermore, article 7 of Law 17/2013 gave the purpose of holding the power on the state finances management, which is to achieve the objectives of Republic of Indonesia as stated on its constitution through the implementation of administration function. This function executed by establishing the annual state budget and local government budget (APBN and APBD).

Article 3 Law 25/2004 stated that national development planning encompasses all integrated aspects of development planning which includes central government's planning - done by ministries and agencies - and local government's planning. The national development planning consists of long-term development plans (RPJPN and RPJPD), medium-term development plans (RPJMN and RPJMD), and annual development plans (RKP and RKPD). Article 4 and 5 Law 25/2004 described the connection of all development plans. In compiling RPJPD, RPJMD, and RKPD, the local government referred to RPJPN, RPJMN, and RKP respectively. The synergy between them is crucial to ensure the objectives of the Republic of Indonesia as one nation are achievable. In addition, article 11, 16, and 22 Law 25/2004 mandated central government and local government to set a deliberation meeting (Musrenbang) on development planning in every level of development plans. It also regulated the involvement of citizen during the meeting.

Moreover, as it defined in article 179 Law 23/2014, APBD is the foundation 
of regional state finances management. Article 180 Law 23/2014, head of local government establishes PPA as a benchmark of drafting the APBD. Furthermore, Article 180 Law 23/2014 instructed local government and DPRD to have discussed on the draft of APBD based on KUA and PPA. Article 69 Law 33/2004 stated that local government initiates APBD based on RKPD, which is referred to RKP as one unify National Development Planning System. More detail on drafting APBD, Article 69 Law 33/2004 listed the source of funding that can be used by local government to finance their development plans, which is local revenues and financing to cover the budget deficit. Local revenues consist of PAD, Transfer Fund, and others legitimate revenues. Law 33/2004 gave freedom to local government to source revenues from their jurisdiction under PAD and others legitimate revenues as the implementation of decentralisation. On the other hand, Law 33/2004 also mandated central government to transfer some of their budget (APBN) to local government in the form of Transfer Fund as a source of funding to delegated authority due to decentralisation. The interconnection between APBD and National Development Planning System as shown in Figure 2.

Figure 2. Interconnection between $\mathrm{APBD}$ and

National Development Planning System

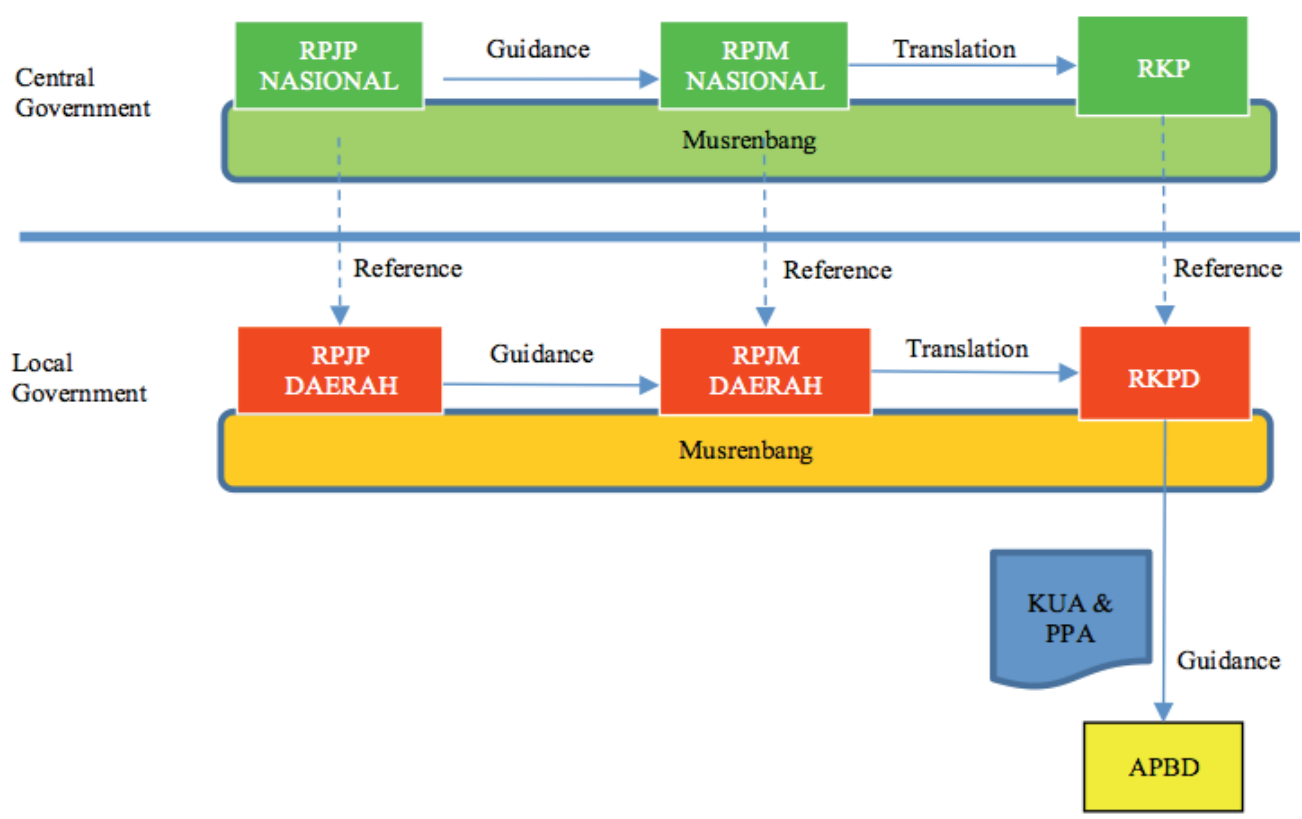

According to article 34 PP 58/2005, the first step of establishing APBD is to assemble KUA based on RKPD. The draft of KUA is being discussed with DPRD as part of the initial discussion on the draft of APBD. Next, as described 
in article 35 PP 58/2005, the final version of KUA is used as a benchmark by local government to draft the PPAS and by DPRD to review the draft of PPAS. when the reviewing process is concluded, KUA and PPA are placed in a memorandum of agreement between local government and DPRD. This memorandum of agreement is the guidance for local government to draft its APBD. Furthermore, article 43 PP 58/2005 instructed head of local government to present the draft of APBD, along with its related documents, to DPRD to have it discussed before approval.

By regulation, not all local government's revenues from central government can be used in accordance with local government aspirations. Nevertheless, according to data released by Directorate General of Fiscal Balance, Ministry of Finance of Indonesia, around 90\% of local government in Indonesia source more than a half of their revenues from Transfer Fund as shown in Table 1. The higher ratio Transfer Fund to Total Local Revenue, the higher dependency of local government to central government in providing public services. Three years average, 2014-2016, on ratio Transfer Fund to Total Local Revenues is about $70 \%$ with almost $60 \%$ of local government above the average.

Table 1. The number of local government based on Ratio Transfer Fund to Total Local Revenues (budget year 2014-2016

\begin{tabular}{|l|l|l|l|}
\hline Ratio Transfer Fund to Total Local Revenues & \multicolumn{1}{|c|}{2016} & \multicolumn{1}{|c|}{2017} & \multicolumn{1}{|c|}{2018} \\
\hline $0-25 \%$ & 7 & 10 & 12 \\
\hline $26 \%-50 \%$ & 29 & 39 & 35 \\
\hline $51 \%-75 \%$ & 241 & 306 & 242 \\
\hline $76 \%-100 \%$ & 265 & 187 & 250 \\
\hline $\begin{array}{l}\text { Average Ratio Transfer Fund to Total Local } \\
\text { Revenues }\end{array}$ & $72.36 \%$ & $67.55 \%$ & $71.04 \%$ \\
\hline $\begin{array}{l}\text { Number of local } \\
\text { government above the average }\end{array}$ & 351 & 295 & 318 \\
\hline
\end{tabular}

Source: Directorate General of Fiscal Balance, Ministry of Finance of Indonesia

The data showed that most of the local government had limited funds for development initiatives. Therefore, alternative sources of funding for local development is necessary for local government. One of them is CSR Funds.

Legislation on CSR in Indonesia can be found on Law 22/2001, Law 25/2007, and Law 40/2007. Article 40 Law 22/2001 stated that the Oil and Natural Gas companies need to be responsible for the development of local environments and communities. Article 15 Law 25/2007 required every investor to implement CSR. Article 1 Law 40/2007 defined CSR as companies' commitment to supporting sustainable economic development in order to enhance the quality of life and 
environment that benefit the company, local community, and the people as a whole. Although, article 74 Law 40/2007 obligated the companies that run its activities on or related to natural resources to have CSR, article 2 PP 47/2012 encouraging CSR for every company. Moreover, article 4 PP 47/2012 regulated the CSR as part of company's annual business plans which approved by Board of Commissioners or General Meeting of Shareholders. Article 6 PP 47/2012 obligated the disclosure of CSR's implementation in the financial statements. Sanction for the noncompliance companies is mandated in article 74 Law 40/2007 and Article 6 PP 47/2012.

Calculating the potential CSR Funds is challenging. While making compulsory for natural resources companies to have CSR, Law 40/2007 did not regulate the portion of CSR Funds needs to be allocated. The only regulation that mentioned the percentage of CSR Funds to companies profit is Ministry of State Owned Enterprises Regulation (Peraturan Menteri BUMN) Per-09/MBU/07/2015, which is $4 \%$ of after-tax income in previous financial statement. Media reported in 2015 that the potential CSR Funds was Rp.12 Trillion per year (Ghofar 2015).

The flow of CSR Funds to local government is a prevailing practice. Such contribution can be direct or indirect. Direct contribution refers to the direct transfer of fund from companies to local government where the usage is up to local government. When the companies provide public facilities or services that part of local government's duty, it can be categorised as an indirect contribution. ${ }^{2}$ However, both approaches are not following budgeting system. Regarding APBD, Law 23/2014 and Law 33/2004 are detailed in Government Regulation (Peraturan Pemerintah/PP) 58/2005. Article 17 PP 58/2005 stressed that all local government revenues and expenditures in the form of cash, goods, and services need to be stated in APBD. Furthermore, article 25 PP 58/2005 listed the unconditional grant from the government, society, and domestic or international business entities in the form of cash, goods, and services as local government's revenue.

As it mandated by regulation, local governments have to include the CSR Funds into their budgeting system if they want to use it as a source of development funding. This paper suggested three stages of integrating CSR Funds into local governments' budgeting system. Each stage represents the number of actors involved during the implementation, which might affect the timeframe of implementation. The stages are short-term, medium-term, and long-term strategy. This separation intended to give clear and measurable target such that each strategy can be implemented independently but still support each other at the same time as one blue print.

${ }^{2}$ Media reports on example of direct and indirect contributions can be found in Kuwado (2013) and Febriani (2016) respectively 
The short-term strategy followed the concept of "Think Outside the Box Inside the Box" where the proposed strategy utilised the available regulations to improve the CSR Funds arrangement into the budgeting system. Therefore, the strategy can be implemented immediately. The medium-term strategy requires regulation improvement to support implementation of the short-term strategy. Lastly, the longterm strategy involves policy from central government to adjust the strategy with the national development plans.

The short-term strategy: Private sectors participation in regional development planning is the key factor in incorporating CSR Funds into the budgeting system. The present regulations facilitate private sectors contributions in development. Their involvements come at multiple events from Musrenbang, for each stage and level, to budget drafting. Local government could take benefit of Musrenbang on RPJPD, RPJMD, and RKPD to promote local government's programs to business entities in their jurisdictions as part of private sectors engagement on local government's development plans. The meeting can be seen as an initial introduction to local government's development plans, therefore, business entities have an idea how to align their CSR policy to local government's development plans. Most major company had established their long-term CSR planning. Therefore, the discussion not merely on shortterm planning, such as annual budget, but also on RPJPD and RPJMD. The followed up discussion is expected to clarify both parties regarding the proposed "shared program" that can be funded by business entities. Such discussion can be held during the PPAS compilation, where programs' priorities and budget allocation are constructed.

This paper also suggested local government to receive CSR Funds, as grants revenue from business entities, in the form of goods or services. This practice could reduce the risk of fraud not only from local government financial management side but also from CSR point of view. Receiving CSR Funds in the form of goods or services hinders local government from the procurement process. According to Handayani (2013), around $70 \%$ of corruption was on the procurement process. By avoiding the procurement process, local government could minimise the change of corruption. From companies' perspective, giving CSR Funds to local government in the form of goods or services could ensure the allocation of CSR Funds is in accordance with companies' concern.

In practice, local government could offer companies some programs that in line with their CSR policy and make the programs as a priority once the companies agree to fund it. Following this scheme, local government could incorporate CSR Funds into their budgeting system as grants revenues in their budget structure. Once 
the $\mathrm{APBD}$ is approved by $\mathrm{DPRD}$, the company run the program and hand it over to local government as grants in the form of goods or services from business entities when it is finished.

The medium-term strategy: Many previous studies emphasised the importance of intense communication between companies and local government to a successful implementation of CSR (Gumuru 2014, Machmud 2015, Muallidin et al. 2016). Many local governments have enacted Perda concerning CSR Forum. Some of them are following defensive approach while others using proactive approach proposed by Ward, Wilson, and Zarsky (2007). Local governments in East Java Province, for example, encouraged business entities to establish a CSR forum. The local governments act as a facilitator of the forum by providing local government's scale development priorities ${ }^{3}$. Some other local governments, e.g. West Java Provincial Government, founded a dedicated team to facilitate local government's development plans to be fitted with business entities' CSR plans instead of having a CSR forum. The team not only assists business entities by supplying local government's development plans document, but also supporting the CSR implementation, control, and evaluation ${ }^{4}$.

The CSR forum helps business entities and local government to synchronising their CSR programs and development plans, respectively. The forum also can be seen as private sectors representative at Musrembang. However, despite mandated the CSR activities to be in line with local government's development plans, none of the regulation enacted by local government obligated its inclusion to APBD through budgeting system. Therefore, improvement in Perda concerning CSR is necessary to straighten and support the implementation of the shortterm strategy. The enhancement also includes: (1) the obligation of including CSR Funds into budgeting system, (2) the obligation of delivering CSR Funds to local government in the form of goods or services, (3) the optimisation of business entities' involvement in local government's development planning, and (4) the optimisation of communication between business entities and local government.

The long-term strategy: The Government of Indonesia shows its commitment to implementing the agenda of Sustainable Development Goals (SDGs) into the RPJMN 2020-2024 (Arifin 2017, Nurmayanti 2017, Nadlir 2017). SDGs are the continuation of the Millennium Development Goals (MDGs) that aims to end poverty, promote prosperity and people's well-being while protecting the environment by 2030 . An integrated approach to sustainable development and collective action is required at all levels to address the challenges of our time, with an overarching im-

\footnotetext{
${ }^{3}$ East Java Province's Perda 4/2011 concerning CSR

${ }^{4}$ West Java Province's Perda 2/2013 concerning CSR
} 
perative of 'leaving no one behind' in achieving this ambitious and universal agenda (UNDG 2016, 1). As a unified system, RPJMD needs to be coherent with RPJMN. Therefore, local government's development initiatives to support SDGs should reflect on their APBD.

The central government is on progress in drafting a comprehensive regulation on the implementation of the SDGs that cover private sectors engagement, integration of the SDGs into development plans and budgets, and institutional arrangements between central government and local government (UNDG 2016). Such policy can be done under the national development planning system framework such as RPJMN. In addition, as SDG-related activities, the central government could use policies on CSR as an instrument to a successful implementation of SDGs in Indonesia.

Most local governments acknowledged the companies that made significant CSR contribution to encourage more. The reward given by local government to business entities are in the form of certificates, plaques, press releases, ease of services, and other incentives 5 . More attractive stimulus could be offered by the central government to increase business entities CSR contribution to local government. As a fiscal manager, the central government could give tax incentives for companies that contribute to local government through CSR. The central government could use this strategy to adjust their policy on SDGs by setting up different tax incentives' requirement for different regions or sectors, for instance.

\section{Conclussion}

The present study aims to investigate the alternative source of development funding for local government. This study proposed strategies to incorporate CSR Funds into local government's budgeting system. The integrating is crucial to achieving accountability. The current paper suggests local government to receive CSR Funds only as goods or services to hinder fraud and misuse. This arrangement gives advantages for both local government and donor company. From the local government's point of view, receiving only goods or services helps local government to reduce the risk of corruption from the procurement process. On the other hand, the donor company would benefit by ensuring their CSR Funds is spent according to its purpose.

To make sure its suggestions are applicable, this study presented its proposed strategies in three categories. The short-term strategy provides an immediate im-

\footnotetext{
${ }^{5}$ Bekasi Regency in Bekasi regency's Perda 6/2015 stated that promotion facilities can be given to business entities as reward for their CSR contribution, while Bogor regency in Bogor regency's Perda 6/2013 offered local tax reduction.
} 
plementation where potential business entities are actively involved during budget preparations, therefore, CSR Funds can be identified and plotted as grants revenue in APBD structure. This strategy can be done in a status quo. The medium-term strategy offers a legal support by putting the short-term strategy as an improvement to the current Perda on CSR. The long-term strategy involves central government's policy not only to optimise CSR funds contribution as local government's development funding but also, at the same time, to successfully implement SDGs agenda in Indonesia.

The current research contributed to enhancing the capacity of local government for development initiative. By investigating the strategy to utilise CSR Funds as a source of development funding, this paper also contributed to provide suggestions for RPJMN 2020-2024 that integrated with SDGs. The primary focus of this research is on budgeting system. Therefore, the discussion on theory and technical side of CSR, including the draft of new legislation on CSR, is off this study's topic. Utilising CSR as an alternative source of development funding is not only applicable to local government but also to the central government. The strategy to utilise CSR Funds as an alternative source of central government's funding is a significant topic for future research.

\section{References}

Arifin, Choirul. 2017. "Bappenas Masukkan 169 Target SDGs di RPJMN 2020-2024." Tribunnews.com, accessed 10 June 2018. http://www. tribunnews.com/bisnis/2017/07/18/bappenas-masukkan-169-targetsdgs-di-rpjmn-2020-2024?page=all.

Febriani, Ririn Nur. 2016. "8 Yayasan dan Panti Terima Dana CSR.” kompas. com, accessed 10 June 2018. http://www.pikiran-rakyat.com/bandungraya/2016/12/16/8-yayasan-dan-panti-terima-dana-csr-387991.

Ghofar, M. 2015. "Rp12 triliun dana CSR Indonesia belum dikelola maksimal." antaranews.com, accessed 10 June 2018. https://www.antaranews.com/ berita/509654/rp12-triliun-dana-csr-indonesia-belum-dikelola-maksimal.

Government of Indonesia. 2005. Government Regulation (PP) 58/2005 concerning Local Government Financial Management. Jakarta.

Government of Indonesia. 2012. Government Regulation (PP) 47/2012 concerning Corporate Social Responsibility. Jakarta.

Gumuru, Denis. 2014. "Peranan Pemerintah Daerah Dalam Meningkatkan Kinerja Corporate Social Responsibility (CSR) Di PT. Nusa Halmahera Minerals." Jurnal Administrasi Publik 2 (002).

Handayani, I Gusti Ayu Ketut Rachmi. 2013. "Korupsi Pengadaan Barang/ jasa Pemerintah: Realitas Antagonis dalam Perwujudan Prinsip Clean Governance di Indonesia.” Masalah-Masalah Hukum 42 (1):6-12.

Isnanto, Bayu Ardi. 2017. "KPK Minta Pemda Hati-hati Pakai Dana CSR." 
detik.com, accessed 10 June 2018. https://news.detik.com/berita/d-3440899/kpk-minta-pemda-hati-hati-pakai-dana-csr.

Kuwado, Fabian Januarius. 2013. "Dinas PU DKI Paling Besar Terima Dana

CSR." kompas.com, accessed 10 June 2018. https://megapolitan.kompas.com/read/2013/07/19/0938530/Dinas.PU.DKI.Paling.Besar.Terima.Dana.CSR.

Machmud, Senen. 2015. "Kajian Pemanfaatan Dana Corporate Social Responsibility Sebagai Alternatif Sumber Pembiayaan Pembangunan Daerah." Jurnal Ekonomi, Bisnis \& Entrepreneurship 9 (1):29-44.

Minister of Home Affairs. 2006. Regulation of Ministry of Home Affairs 13/2006 concerning the Guidelines of Local Government Financial Management. Jakarta.

Minister of State Owned Enterprises. 2015. Ministry of State Owned Enterprises Regulation Per-09/MBU/07/2015. Jakarta.

Muallidin, Isnaini, Mukti Fajar Dewata, Leli Joko Suryono, And Dyah Mutiarin. 2016. "Kebijakan Corporate Social Responsibility (CSR) Pemerintah Daerah dalam Perspektif Teori Kelembagaan: Studi di DIY dan Provinsi Jawa Tengah.” Seminar Nasional II FISIP Universitas Andalas, Padang.

Nadlir, Moh. 2017. "RI Akan Implementasikan 169 Agenda Sustainable Development Goals." Kompas.com, accessed 10 June 2018. https:// ekonomi.kompas.com/read/2017/07/18/212201626/ri-akan-implementasikan-169-agenda-sustainable-development-goals.

Nasution, Anwar. 2016. Government Decentralization Program in Indonesia. Asian Development Bank Institute.

Nurmayanti. 2017. "Bappenas Masukkan 169 Target SDGs dalam RPJMN 2020-2024." Liputan6.com, accessed 10 June 2018. https://www. liputan6.com/bisnis/read/3026574/bappenas-masukkan-169-target-sdgs-dalam-rpjmn-2020-2024.

Regional Secretary, of Bogor Regency. 2013. Bogor Regency Regulation 6/2013 concerning CSR. Bogor.

Regional Secretary, of Bekasi Regency. 2015. Bekasi Regency Regulation 6/2015 concerning CSR. Bekasi.

Regional Secretary, of East Java Province. 2011. East Java Provincial Regulation 4/2011 concerning CSR. Surabaya.

Regional Secretary, of West Java Province. 2013. West Java Provincial Regulation 2/2013 concerning CSR. Bandung.

Rusmin, Rusmin, Emita W Astami, and Glennda Scully. 2014. "Local Government Units in Indonesia: Demographic Attributes and Differences in Financial Condition.” Australasian Accounting Business \& Finance Journal 8 (2):88.

State Secretary of Indonesia. 1945. The 1945 Constitution of the Republic of Indonesia. Jakarta. 
State Secretary of Indonesia. 1999. Law 22/1999 concerning Regional Governance. Jakarta.

State Secretary of Indonesia. 1999. Law 25/1999 concerning Balance of Finance between Central Government and Local Government. Jakarta.

State Secretary of Indonesia. 2001. Law 22/2001 concerning Oil and Natural Gas. Jakarta.

State Secretary of Indonesia. 2003. Law 17/2003 concerning The State Finances. Jakarta.

State Secretary of Indonesia. 2004. Law 25/2004 concerning National Development Planning System. Jakarta.

State Secretary of Indonesia. 2004. Law 23/2014 concerning Regional Governance. Jakarta.

State Secretary of Indonesia. 2004. Law 33/2004 concerning Balance of Finance between Central Government and Local Government. Jakarta.

State Secretary of Indonesia. 2007. Law 40/2007 concerning Indonesian Limited Liability Company (Perseroan Terbatas/PT). Jakarta.

State Secretary of Indonesia. 2007. Law 25/2007 concerning Capital Investment. Jakarta.

Subekan, Achmat. 2016. "Potensi Zakat Menjadi Bagian Keuangan Negara “ Jurisdictie: Jurnal Hukum dan Syariah 7 (2).

UNDG, United Nations Development Group. 2016. The Sustainable Development Goals are Coming to Life: Stories Of Country Implementation and Un Support. USA: United Nations Development Group.

Ward, Halina, Emma Wilson, and Lyuba Zarsky. 2007. "CSR and Developing Countries." Sustainable Development Innovation Briefs (1). 